\title{
A meta-analysis of the factors affecting eWOM providing behaviour
}

\author{
Elvira Ismagilova, University of Bradford, United Kingdom \\ Nripendra P. Rana, University of Bradford, United Kingdom \\ Emma Slade, University of Bristol, United Kingdom \\ Yogesh K. Dwivedi, Swansea University, United Kingdom
}

\begin{abstract}
Purpose- Numerous studies have examined factors influencing eWOM providing behaviour. The volume of extant research and inconsistency in some of the findings makes it useful to develop an all-encompassing model synthesising results. Therefore, the aim of this study is to synthesise findings from existing studies on eWOM by employing meta-analysis, which will help to reconcile conflicting findings of factors affecting consumers' intention to engage in eWOM communications.
\end{abstract}

Design/methodology/approach- The findings from 51 studies were used for meta-analysis, which was undertaken using Comprehensive Meta-Analysis software.

Findings- Factors affecting eWOM providing behaviour were divided into four groups: personal conditions, social conditions, perceptual conditions, and consumption-based conditions. The results of meta-analysis showed that out of 20 identified relationships, 16 were found to be significant (opinion seeking, information usefulness, trust in web eWOM services, economic incentive, customer satisfaction, loyalty, brand attitude, altruism, affective commitment, normative commitment, opinion leadership, self-enhancement, information influence, tie strength, homophily, and community identity).

Originality/value- Applying meta-analysis helped reconciliation of conflicting findings, enabled investigation of the strengths of the relationships between motivations and eWOM providing behaviour, and offered a consolidated view. The results of this study facilitate the advancement of current knowledge of information dissemination on the Internet, which can influence consumer purchase intention and loyalty.

Keywords: Electronic word of mouth (eWOM), meta-analysis, motivations to provide eWOM, eWOM engagement

Paper type: Research paper

\section{Introduction}

With the advancement of Internet technologies, consumers increasingly use electronic word of mouth (eWOM) communications as a helpful tool when seeking information. eWOM is defined as the dynamic and ongoing information exchange process between potential, actual, or former consumers regarding a product, service, brand, or company, which is available to a multitude of individuals and institutions via the Internet (Dwivedi et al., 2020; Hennig- 
Thurau et al., 2004; Ismagilova et al., 2017). Numerous studies (e.g. Bairrada et al., 2018; Chen and Huang, 2013; Chiu et al., 2014; Japutra et al., 2018; Reimer and Benkenstein, 2016; Singh and Söderlund, 2020; Thakur, 2019; Wolny and Mueller, 2013; Wu and Wang, 2017; Wu et al., 2016) have examined factors influencing individuals to provide eWOM communications. Investigating consumers' motivations to provide eWOM helps researchers and practitioners to understand and encourage or discourage information assimilation on the Internet, which can influence consumers' purchase intentions, loyalty, and commitment (Dessart et al., 2019; Yan et al., 2018). However, insights from eWOM research on the topic of engagement in eWOM, particularly eWOM providing behaviour, have not always been cumulative, and some studies have reported conflicting results about the effect of factors, such as incentives (Hennig-Thurau et al., 2004; Yoo et al., 2013), opinion seeking (Magalhaes and Musallam, 2014; Nagy et al., 2017), involvement (Alhidari et al., 2015; Sohn, 2009), brand attitude (Rialti et al., 2017; Yeh and Choi, 2011), altruism (Horng, 2016; Reimer and Benkenstein, 2016), customer satisfaction (Luarn et al., 2015; Son et al., 2012), and self-enhancement (Magalhaes and Musallam, 2014; Tong et al., 2013) to name a few, on eWOM providing behaviour. Therefore, the aim of this study is to synthesise findings from existing studies on eWOM providing behaviour by employing meta-analysis to answer the research question: What factors are related to eWOM providing behaviour?

Engagement in eWOM communications is one of the popular areas in eWOM research (Chen et al., 2018; Naumann et al., 2020; Palmeira et al., 2020; Reimer and Benkenstein, 2016). Engagement is defined as "a customer's personal connection to a brand as manifested in cognitive, affective, and behavioural responses outside of the purchase situation" (So et al., 2014, p.310). eWOM engagement behaviours include eWOM seeking and eWOM providing (Ismagilova et al., 2017). Alwash et al. (2019) distinguish two levels of eWOM providing behaviour: shallow and deep. The shallow level involves consumers performing an action of low cognitive effort and takes place within a short duration. Examples of shallow eWOM providing behaviours include "liking" and sharing existing content (Alwash et al., 2019; Ananda et al., 2019), which are quickly undertaken with minimal effort. On the other hand, the deep level involves higher cognitive effort and takes a longer duration. Examples of deep eWOM providing behaviours include creating or producing content, such as reviews, and commenting on others' eWOM communications (Alwash et al., 2019; Ananda et al., 2019). This research focuses on eWOM providing behaviour at both levels.

Researchers have suggested that it is important to examine the common factors of eWOM providing behaviour across various product categories (Amed et al., 2019). The volume of extant research and inconsistency in some of the findings makes it useful to develop an allencompassing model synthesising results relevant to this topic. Despite significant insight provided by previous research on eWOM communications (Floyd et al., 2014; Hong et al., 2017), a consensus regarding the factors affecting eWOM providing behaviour is yet to emerge (Amed et al., 2019), indicating the need for a systematic integration of this body of work, which will help to advance the knowledge of online information dissemination. 
It is common to have mixed research results in social and behavioural studies (Hong et al., 2017). To find a common truth behind conceptually similar studies, researchers apply metaanalysis. Meta-analysis is an important and powerful tool as some of the studies lack sufficient power to achieve statistically significant results (Geyskens et al., 2009; King and He, 2006; Pan et al., 2012). By combining findings from numerous independent studies on the same relationship into a single estimate, meta-analysis helps researchers to make more accurate conclusions in comparison with the ones presented in any primary study (Geyskens et al., 2009; Schmidt and Hunter, 2014).

Meta-analysis has been used in previous eWOM research (Table 1). Most of the metaanalysis studies on eWOM focused on eWOM persuasiveness and the impact of eWOM on sales/intention to buy. Previous meta-analysis studies (e.g. Babić Rosario et al., 2016; Ismagilova et al., 2019) provided clarity on the conflicting results of various factors in eWOM research and proposed valuable guidance on variable selections for future studies. For example, using 96 studies Babić Rosario et al. (2016) examined the effect of eWOM characteristics, volume, and valence on sales, finding that eWOM volume has a stronger impact on sales in comparison with eWOM valence. Another study by Ismagilova et al. (2019) investigated the effect of eWOM communication on consumer intention to buy. Previous studies in the eWOM field (e.g. Frasquet et al., 2015; Teng et al., 2017) had mixed findings regarding the effect of factors such as eWOM usefulness, valence, and volume on consumer behaviour. Utilising findings from 59 studies, Ismagilova et al. (2019) found that eWOM usefulness, valence, and volume have a significant impact on consumer buying intention. It was proposed that results of the meta-analysis could be used as a guideline for future empirical research.

While the previous studies discussed above are valuable, they do not explain why consumers engage in eWOM providing behaviour. This study will maximise the benefits of the existing research on eWOM and produce accumulated knowledge by assessing the empirical evidence across multiple studies on eWOM providing behaviour (Grewal et al., 2018). Similar to previous eWOM meta-analysis research (Babić Rosario et al., 2016; Floyd et al., 2014; Ismagilova et al., 2020; You et al., 2015), this study will reconcile conflicting results, which will advance eWOM research. The study will set the agenda for future research directions on factors related to eWOM providing behaviour. Based on this study, scholars will be able to deduce the variables to be selected for analysing consumers' eWOM providing behaviour. The findings will help to understand and predict information exchange behaviour on the Internet (Han, 2008), which in turn can help influence purchase decision and sales volume (Hennig-Thurau and Walsh, 2003).

Table 1. Summary of previous meta-analysis studies on eWOM

\begin{tabular}{|l|l|c|l|}
\hline \multicolumn{1}{|c|}{ Study } & Aim of the study & $\begin{array}{c}\text { Number of } \\
\text { studies used for } \\
\text { meta-analysis }\end{array}$ & $\begin{array}{c}\text { Techniques/Software } \\
\text { used for meta- } \\
\text { analysis }\end{array}$ \\
\hline $\begin{array}{l}\text { Floyd et al. } \\
\text { (2014) }\end{array}$ & $\begin{array}{l}\text { Investigate how valence and volume } \\
\text { influence the elasticity of retailer sales. }\end{array}$ & 26 & Elasticities \\
\hline You et al. & Investigate the direct effect of eWOM & 51 & Elasticities \\
\hline
\end{tabular}




\begin{tabular}{|l|l|c|l|}
\hline$(2015)$ & on sales. & & \\
\hline $\begin{array}{l}\text { Babić } \\
\text { Rosario et al. } \\
(2016)\end{array}$ & $\begin{array}{l}\text { Investigate the influence of platform } \\
\text { characteristics, product characteristics, } \\
\text { and eWOM metrics on the relationship } \\
\text { between eWOM and sales. }\end{array}$ & 96 & $\begin{array}{l}\text { Correlation } \\
\text { coefficients }\end{array}$ \\
\hline $\begin{array}{l}\text { Hong et al. } \\
(2017)\end{array}$ & $\begin{array}{l}\text { Investigate factors affecting } \\
\text { helpfulness of online reviews. }\end{array}$ & 42 & $\begin{array}{l}\text { Correlation } \\
\text { coefficients, } \\
\text { Comprehensive Meta- } \\
\text { Analysis (CMA) 2.0 }\end{array}$ \\
\hline $\begin{array}{l}\text { Ismagilova } \\
\text { et al. (2019) }\end{array}$ & $\begin{array}{l}\text { Investigate factors affecting intention } \\
\text { to buy. }\end{array}$ & 69 & $\begin{array}{l}\text { Correlation } \\
\text { coefficients, } \\
\text { Comprehensive Meta- } \\
\text { Analysis (CMA) 2.0 }\end{array}$ \\
\hline $\begin{array}{l}\text { Ismagilova } \\
\text { et al. (2020) }\end{array}$ & $\begin{array}{l}\text { Investigate the effect of characteristics } \\
\text { of source credibility on consumer } \\
\text { behaviour. }\end{array}$ & 20 & $\begin{array}{l}\text { Correlation } \\
\text { coefficients, } \\
\text { Comprehensive Meta- } \\
\text { Analysis (CMA) 2.0 }\end{array}$ \\
\hline
\end{tabular}

The rest of the paper is structured as follows. Section 2 presents the framework and hypotheses development, followed by section 3 which describes the research methodology used for this study. Then, section 4 presents the findings from meta-analysis. The findings are discussed in section 5, outlining theoretical contributions of the research, as well as limitations and future research directions.

\section{Framework and hypotheses}

A number of studies have investigated the factors affecting eWOM providing behaviour. It has been argued that the literature on factors affecting eWOM providing behaviour is fragmented and discrete (Hennig-Thurau et al., 2004; Teng et al., 2016). Research has focused on various contexts, such as virtual communities (Chi-Hsing, 2014), online opinion platforms (Jin et al., 2010), and social networking sites (SNS) (Alhidari et al., 2015), as well as different products/services, such as laptops (Lii and Lee, 2012), fashion products (Saleem and Ellahi, 2017), digital cameras (Sohn, 2009), hotels (Yen and Tang, 2015), and restaurants (De Meyer and Petzer, 2014). As already mentioned, results from different studies regarding antecedents of eWOM providing behaviour have been contradictory. Different approaches have been taken by eWOM researchers to identify and conceptualise factors affecting eWOM providing behaviour. Some studies use specific theories and frameworks to categorise factors (Cui et al., 2014; Okazaki, 2009; Tong et al., 2013), such as social exchange theory (Cui et al., 2014), motivational theory (e.g. Tong et al., 2013), and uses \& gratifications (U\&G) theory (e.g. Plume and Slade, 2018), while others do not. As a result, studies have called for more research (Amed et al., 2019).

Previous eWOM research distinguishes various groups of consumer motivations based on the framework proposed by Palka et al. (2009), which used grounded theory to discuss individuals' motivations to disseminate information using mobile devices (Cheung et al., 2015; Luarn et al., 2015). According to this framework motivations can be classified according to five conditions: social, attitudinal (perceptual), resource-based, customer-based, and personal. These conditions were built from various constructs that can influence 
individuals' behaviour to disseminate information. Numerous studies adapted the framework by Palka et al. (2009) to study eWOM providing behaviour online (Cheung et al., 2015; Luarn et al., 2015). For example, Luarn et al. (2015) used four of the conditions - they excluded resource-based motivations as they argued that the costs of disseminating information via the Internet are difficult to perceive, unlike costs associated with information dissemination through mediums such as mobile SMS.

Given the range of studies that have researched factors affecting eWOM providing behaviour from different viewpoints as well as theoretical underpinnings (e.g. Cui et al., 2014; HenningThurau et al., 2004; Jin et al., 2010; Okazaki, 2009; Tong et al., 2013), the use of one single background theory to inform the current study is problematic. Therefore, it is useful to consider all factors from a higher vantage point. To help in this endeavour, the classification framework provided by Palka et al. (2009), based on grounded theory, offers a broad framework to consider all the factors identified holistically. Based on the groupings of factors in other eWOM studies (Luarn et al., 2015; Palka et al., 2009), factors affecting eWOM providing behaviour were divided into four groups: personal conditions, social conditions, perceptual conditions, and consumption-based conditions.

Table 2 presents a description of the 20 factors, including a definition, different labels used for the same construct by different studies in the sample, and examples of some representative studies, specifying whether they found the effect of the construct on eWOM providing behaviour to be significant or not.

Table 2. Factors affecting eWOM providing behavior

\begin{tabular}{|c|c|c|c|}
\hline Category & Construct & Definition & References \\
\hline \multirow[t]{4}{*}{$\begin{array}{l}\text { Perceptual } \\
\text { conditions }\end{array}$} & $\begin{array}{l}\text { Opinion } \\
\text { seeking }\end{array}$ & $\begin{array}{l}\text { Behaviour focused on looking } \\
\text { for eWOM communications. } \\
\text { Variables included: opinion } \\
\text { seeking, obtain information, } \\
\text { advice seeking. }\end{array}$ & $\begin{array}{l}\text { Significant: Hennig-Thurau et al. } \\
\text { (2004); Huang et al. (2013); } \\
\text { Kucukemiroglu and Kara (2015); } \\
\text { Nagy et al. (2017); Sun et al. } \\
\text { (2006). } \\
\text { Non-significant: Magalhaes and } \\
\text { Musallam (2014). }\end{array}$ \\
\hline & $\begin{array}{l}\text { Information } \\
\text { usefulness }\end{array}$ & $\begin{array}{l}\text { The degree to which the } \\
\text { information assists consumers } \\
\text { in making their purchase } \\
\text { decisions. } \\
\text { Variables included: } \\
\text { information usefulness, } \\
\text { helpfulness, diagnosticity. }\end{array}$ & $\begin{array}{l}\text { Significant: Bobkowski (2015); } \\
\text { Frasquet et al. (2015); Huang et } \\
\text { al. (2013). }\end{array}$ \\
\hline & Perceived risk & $\begin{array}{l}\text { The uncertainty a consumer } \\
\text { has in making a purchase } \\
\text { decision. } \\
\text { Variables included: perceived } \\
\text { risk, risk reduction. }\end{array}$ & $\begin{array}{l}\text { Significant: Song and Sun } \\
\text { (2011); Tirunillai and Tellis } \\
\text { (2012); Zhang and Lv (2010). }\end{array}$ \\
\hline & $\begin{array}{l}\text { Trust in web } \\
\text { eWOM } \\
\text { services }\end{array}$ & $\begin{array}{l}\text { The subjective belief that a } \\
\text { party will fulfil their } \\
\text { obligations. } \\
\text { Variables included: trust in } \\
\text { web eWOM services, }\end{array}$ & $\begin{array}{l}\text { Significant: Filieri et al. (2015); } \\
\text { Frasquet et al. (2015); Horng } \\
\text { (2016); Nusair et al. (2017). }\end{array}$ \\
\hline
\end{tabular}




\begin{tabular}{|c|c|c|c|}
\hline & & perceived security. & \\
\hline & $\begin{array}{l}\text { Economic } \\
\text { incentive }\end{array}$ & $\begin{array}{l}\text { Acquiring economic benefits } \\
\text { (e.g. money, web coupons, free } \\
\text { delivery). } \\
\text { Variables included: economic } \\
\text { incentive, remuneration, } \\
\text { extrinsic reward, open market } \\
\text { reward. }\end{array}$ & $\begin{array}{l}\text { Significant: Hansen and Lee } \\
\text { (2013); Hennig-Thurau et al. } \\
\text { (2004); Horng (2016); Lee et al. } \\
\text { (2013); Luarn et al. (2015); Son } \\
\text { et al. (2012); Yoo et al. (2013). } \\
\text { Non-significant: Cui et al. } \\
\text { (2014); Reimer and Benkenstein } \\
\text { (2016); Shen et al. (2011); Yen } \\
\text { and Tang, (2015); Tong et al. } \\
\text { (2013). }\end{array}$ \\
\hline \multirow[t]{4}{*}{$\begin{array}{l}\text { Consumption- } \\
\text { based } \\
\text { conditions }\end{array}$} & Involvement & $\begin{array}{l}\text { The degree of psychological } \\
\text { identification and emotional } \\
\text { ties the receiver has with the } \\
\text { product/service. } \\
\text { Variables included: } \\
\text { involvement level, } \\
\text { involvement. }\end{array}$ & $\begin{array}{l}\text { Significant: Alhidari et al. } \\
\text { (2015); Cui et al. (2014); De } \\
\text { Meyer and Petzer (2014); Saleem } \\
\text { and Ellahi (2017); Song and Sun } \\
\text { (2011); Sotiriadis and van Zyl } \\
\text { (2013); Wolny and Mueller } \\
\text { (2013). } \\
\text { Non-significant: Sohn (2009). }\end{array}$ \\
\hline & $\begin{array}{l}\text { Customer } \\
\text { satisfaction }\end{array}$ & $\begin{array}{l}\text { A condition that happens as a } \\
\text { result of a pleasant } \\
\text { consumption fulfilment. } \\
\text { Variables included: customer } \\
\text { satisfaction, successful } \\
\text { experience, open market } \\
\text { satisfaction, satisfaction with } \\
\text { service recovery. }\end{array}$ & $\begin{array}{l}\text { Significant: Lii and Lee (2012); } \\
\text { Luarn et al. (2015); Moliner- } \\
\text { Velázquez et al. (2015); Shen et } \\
\text { al. (2011); Ziegele and Weber } \\
\text { (2015). } \\
\text { Non-significant: Horng (2016); } \\
\text { Lee et al. (2013); Son et al. } \\
\text { (2012). }\end{array}$ \\
\hline & Loyalty & $\begin{array}{l}\text { Overall attachment with a } \\
\text { favourable attitude manifested } \\
\text { by repeated purchasing. } \\
\text { Variables included: open } \\
\text { market loyalty, customer } \\
\text { loyalty. }\end{array}$ & $\begin{array}{l}\text { Significant: Gumus and Bal } \\
\text { (2016); Lee et al. (2013); Son et } \\
\text { al. (2012). }\end{array}$ \\
\hline & Brand attitude & $\begin{array}{l}\text { Favourable attitude toward the } \\
\text { brand. }\end{array}$ & $\begin{array}{l}\text { Significant: Rialti et al. (2017). } \\
\text { Non-significant: Yeh and Choi } \\
\text { (2011). }\end{array}$ \\
\hline \multirow[t]{3}{*}{$\begin{array}{l}\text { Personal } \\
\text { conditions }\end{array}$} & Altruism & $\begin{array}{l}\text { The aim of increasing welfare } \\
\text { of one or more person(s) other } \\
\text { than oneself. } \\
\text { Variables included: altruism, } \\
\text { altruistic motive, affection, } \\
\text { outcome expectations (care } \\
\text { about others), enjoyment in } \\
\text { helping other consumers, } \\
\text { satisfaction in helping other } \\
\text { customers }\end{array}$ & $\begin{array}{l}\text { Significant: Cheung and Lee } \\
\text { (2012); Cui et al (2014); Kim } \\
\text { (2017); Luarn et al. (2015); } \\
\text { Okazaki (2009); Reimer and } \\
\text { Benkenstein (2016); Tong et al. } \\
\text { (2013); Yang (2013); Zhang and } \\
\text { Lv (2010). } \\
\text { Non-significant: Horng (2016); } \\
\text { Morrongiello et al. (2017); Yen } \\
\text { and Tang (2015). }\end{array}$ \\
\hline & $\begin{array}{l}\text { Affective } \\
\text { commitment }\end{array}$ & $\begin{array}{l}\text { Emotional commitment } \\
\text { derived from emotional } \\
\text { attachment to, identification } \\
\text { with, and involvement in an } \\
\text { entity. }\end{array}$ & $\begin{array}{l}\text { Significant: Jin et al. (2010); Li } \\
\text { et al. (2016). }\end{array}$ \\
\hline & $\begin{array}{l}\text { Normative } \\
\text { commitment }\end{array}$ & $\begin{array}{l}\text { Motivated by the actor's moral } \\
\text { obligation that they must fulfil. }\end{array}$ & $\begin{array}{l}\text { Significant: Jin et al. (2010); Li } \\
\text { et al. (2016). }\end{array}$ \\
\hline
\end{tabular}




\begin{tabular}{|c|c|c|c|}
\hline & $\begin{array}{l}\text { Opinion } \\
\text { leadership }\end{array}$ & $\begin{array}{l}\text { A domain-independent, trait- } \\
\text { like set of personality } \\
\text { characteristics that are stable } \\
\text { over time and across } \\
\text { respondent groups. Opinion } \\
\text { leaders shape public opinion } \\
\text { by selectively conveying mass } \\
\text { media messages to their social } \\
\text { networks. }\end{array}$ & $\begin{array}{l}\text { Significant: Bobkowski (2015); } \\
\text { Kucukemiroglu and Kara (2015); } \\
\text { Sun et al. (2006). }\end{array}$ \\
\hline & $\begin{array}{l}\text { Self- } \\
\text { enhancement }\end{array}$ & $\begin{array}{l}\text { Presenting themselves } \\
\text { positively, sharing information } \\
\text { to look good. } \\
\text { Variables included: } \\
\text { extraversion, positive self- } \\
\text { enhancement, image outcome } \\
\text { expectations, self-presentation, } \\
\text { self-improvement, self- } \\
\text { expression. }\end{array}$ & $\begin{array}{l}\text { Significant: Cheung and Lee } \\
\text { (2012); Christodoulides et al., } \\
\text { 2012; Cui et al (2014); Hennig- } \\
\text { Thurau et al. (2004); Horng } \\
\text { (2016); Kim (2017); Lee et al. } \\
\text { (2013); Maceli et al. (2015); } \\
\text { Magalhaes and Musallam (2014); } \\
\text { Okazaki (2009); Son et al. } \\
\text { (2012); Tong et al. (2013); Wu et } \\
\text { al. (2016). } \\
\text { Non-significant: Horng (2016). }\end{array}$ \\
\hline \multirow[t]{6}{*}{$\begin{array}{l}\text { Social } \\
\text { conditions }\end{array}$} & $\begin{array}{l}\text { Influence of } \\
\text { others }\end{array}$ & $\begin{array}{l}\text { Influence of the behaviours, } \\
\text { beliefs and practices of other } \\
\text { users. } \\
\text { Variables included: norms, } \\
\text { normative influence, influence } \\
\text { of others, normative pressure, } \\
\text { subjective norms. }\end{array}$ & $\begin{array}{l}\text { Significant: Chu and Kim } \\
\text { (2011); Hansen and Lee (2013); } \\
\text { Shan and King (2015). } \\
\text { Non-significant: Choi and Scott } \\
\text { (2013); Magalhaes and Musallam } \\
\text { (2014). }\end{array}$ \\
\hline & $\begin{array}{l}\text { Information } \\
\text { influence }\end{array}$ & $\begin{array}{l}\text { Capacity to accept information } \\
\text { from another knowledgeable } \\
\text { person to select a product or } \\
\text { brand. } \\
\text { Variables included: } \\
\text { information influence, power. }\end{array}$ & $\begin{array}{l}\text { Significant: Wu et al. (2016). } \\
\text { Non-Significant: Chu and Kim } \\
\text { (2011); Saleem and Ellahi } \\
\text { (2017). }\end{array}$ \\
\hline & Tie strength & $\begin{array}{l}\text { The depth of a relationship } \\
\text { between information source } \\
\text { and information seeker. } \\
\text { Variables included: tie } \\
\text { strength, social interaction tie, } \\
\text { perceived social relationships. }\end{array}$ & $\begin{array}{l}\text { Significant: Luarn et al. (2015); } \\
\text { Men and Muralidharan (2017); } \\
\text { Niu et al. (2010); Wolny and } \\
\text { Mueller (2013). } \\
\text { Non-significant: Chu and Kim } \\
\text { (2011); Hansen and Lee (2013). }\end{array}$ \\
\hline & Homophily & $\begin{array}{l}\text { The degree to which two or } \\
\text { more individuals who interact } \\
\text { are similar in certain attributes } \\
\text { (e.g. beliefs, education, social } \\
\text { status). } \\
\text { Variables included: } \\
\text { homophily, rapport. }\end{array}$ & $\begin{array}{l}\text { Significant: Saleem and Ellahi } \\
\text { (2017). } \\
\text { Non-significant: Chu and Kim } \\
\text { (2011); Hansen and Lee (2013). }\end{array}$ \\
\hline & Reciprocity & $\begin{array}{l}\text { Benefit for individuals to } \\
\text { engage in social exchange; a } \\
\text { person who offers help to } \\
\text { others expecting returns in the } \\
\text { future. }\end{array}$ & $\begin{array}{l}\text { Significant: Cheung and Lee } \\
\text { (2012); Horng (2016). } \\
\text { Non-significant: Horng (2016). }\end{array}$ \\
\hline & Community & Sense of belonging to the & Significant: Chi-Hsing (2014); \\
\hline
\end{tabular}




\begin{tabular}{|l|l|l|l|}
\hline & identity & $\begin{array}{l}\text { virtual (online) community. } \\
\text { Variables included: community } \\
\text { identification, social } \\
\text { identification. }\end{array}$ & $\begin{array}{l}\text { Yoo et al. (2013). } \\
\text { Non-significant: Horng (2016). }\end{array}$ \\
\hline
\end{tabular}

Note: Some of the studies presented in the table have more than one data set

\subsection{Perceptual conditions}

Perceptual conditions are indicators of the subjectivity or objectivity of various perception attributes (Palka et al., 2009). The perceptual process is influenced by an individual's level of involvement, which has an impact on the information that they focus on and provide. The perceptual condition in this study included five categories: opinion seeking, information usefulness, perceived risk, trust in web eWOM services, and economic incentives.

Opinion seeking. Opinion seeking is defined as a behaviour focused on looking for eWOM communications (Hennig-Thurau et al., 2004). By providing eWOM, individuals can offer or solicit an opinion regarding how to solve a problem and they can obtain more specific and useful feedback (Magalhaes and Musallam, 2014). Some researchers suggest that many people who share information online also seek information online because of their desire for more knowledge (Sun et al., 2006). It is suggested that, because of the potential to acquire a large amount of information, people who seek information will engage in providing eWOM. Some studies (e.g. Kucukemiroglu and Kara, 2015; Nagy et al., 2017; Sun et al., 2006) investigated the link between opinion seeking and opinion providing. For instance, by conducting surveys with 1,000 consumers from Hungary, Nagy et al. (2017) found that online opinion seeking has a positive effect on providing opinions online. Thus, the following hypothesis can be formulated:

\section{H1: Opinion seeking is positively related to eWOM providing behaviour.}

Information usefulness. Information usefulness or helpfulness refers to the degree to which the information assists consumers in making their purchase decision (Davis, 1989). Previous studies (e.g. Bobkowski, 2015; Huang et al., 2013) found that perceived information usefulness can significantly affect consumer behaviour. Using information utility theory, Bobkowski (2015) found that perceived information usefulness has a significant positive impact on news-sharing intention. Another study by Huang et al. (2013) found that perceived message usefulness is positively related to information sharing behaviour of Chinese consumers. By sharing information that is perceived as useful, individuals can contribute to the online environment. Thus, based on the above discussion the following is hypothesised:

\section{H2: Information usefulness is positively related to eWOM providing behaviour.}

Perceived risk. Perceived risk refers to the uncertainty a consumer has in making a purchase decision (Zhang and Lv, 2010). Previous research argues that if consumers can perceive a risk of consumption, they are more likely to search for information and spread it through the Internet (Zhang and Lv, 2010). A number of studies (Song and Sun, 2011; Tirunillai and Tellis, 2012; Zhang and Lv, 2010) investigated the link between perceived risk and eWOM related behaviour. For example, Zhang and Lv (2010) found that perceived risk has a positive 
correlation with eWOM providing behavior and has a significant impact on it. Thus, based on the above discussion, the following hypothesis is proposed:

\section{H3: Perceived risk is positively related to eWOM providing behaviour.}

Trust in web eWOM services. Trust in web services refers to the subjective belief that a party will fulfil their obligations (Filieri et al., 2015; Frasquet et al., 2015). Researchers argue that if consumers trust consumer-generated media they will be more willing to talk to other people about the website and experience they had while using it. The more individuals are confident about the trustworthiness of a consumer-generated media website the more likely they will tell others about it, as the perceived risk of deception from this source of advice is low (Filieri et al., 2015). A number of studies (e.g. Filieri et al., 2015; Frasquet et al., 2015; Horng, 2016; Nusair et al., 2017) investigated the relationship between trust in web eWOM services and eWOM engagement behaviour. For example, using 1533 respondents from UK and Spain, Frasquet et al. (2015) found that consumer trust towards consumer-generated media positively influences eWOM in the context of apparel and consumer electronics. Based on the above discussion the following is hypothesised:

H4: Trust in web eWOM services is positively related to eWOM providing behaviour.

Economic incentives. Economic incentives are considered to be an important external motivational factor (Henning-Thurau et al., 2004). When an individual considers that the reward exceeds the costs of conducting a certain behaviour, the behaviour tends to occur more often (Son et al., 2012). Previous research suggests that using money as a reward is an important extrinsic motivational factor, which helps to improve individuals' participation level and execution level (Orlikowski, 1993). Economic incentives in this context refers to the reward of economic benefits (e.g. money, web coups, free delivery) for participating in eWOM behaviours (Cui et al., 2014; Henning-Thurau et al., 2004). A study conducted by Henning-Thurau et al. (2004) found that economic incentives are an important factor in eWOM spreading and contribute to the sharing of experiences and knowledge online among consumers. Thus, based on the previous discussion the following is hypothesised:

H5: Economic incentive is positively related to eWOM providing behaviour.

\subsection{Consumption-based conditions}

Consumption-based conditions include consumption-related indicators (Chu and Kim, 2011; Luarn et al., 2015; Palka et al., 2009). Consumption-based conditions in this study included involvement, customer satisfaction, loyalty, and brand attitude.

Involvement. Involvement refers to the degree of psychological identification the receiver has with a product/service (Zaiehkowsky, 1985). It was found by Dichter (1966) that differences in product involvement influences motivation to spread WOM about products. If the degree of involvement is high, consumers will pay more attention to a particular product and its information. After the purchase, it is expected that consumers will have a greater emotional response and consequently a stronger desire to share information regarding this product 
(Alhidari et al., 2015; Cui et al., 2014, De Meyer and Petzer, 2014; Saleem and Ellahi, 2017). Thus, the following hypothesis is proposed:

H6: Involvement is positively related to eWOM providing behaviour.

Customer satisfaction. Customer satisfaction is defined as a condition that happens as a result of a pleasant consumption fulfilment (Oliver, 1997). It has been found that customer satisfaction significantly affects consumer behaviour, such as attitude towards product, loyalty towards a brand, and intention to spread eWOM to name a few (Luarn et al., 2015; Moliner-Velázquez et al., 2015; Shen et al., 2011). Some studies (Luarn et al., 2015; MolinerVelázquez et al., 2015; Shen et al., 2011) have investigated how satisfaction with service recovery affects behaviour connected to providing eWOM communications. As customers' expectations are exceeded, individuals feel a need to engage in eWOM providing behaviour to share with their positive experience. As a result, the following is hypothesised:

\section{H7: Customer satisfaction is positively related to eWOM providing behaviour.}

Loyalty. Loyalty is defined as an overall attachment with a favourable attitude manifested by repeated purchasing (Oliver, 1999). Studies (Sichtmann, 2007; Walsh and Beatty, 2007) highlight several important consequences of loyalty, which include repeating purchase and recommendations to others (eWOM). If an individual has a psychological attachment towards a product/service/vendor/market, the individual will be willing to share their own experience with others (Son et al., 2012). Previous studies (Gumus and Bal, 2016; Lee et al., 2013; Son et al., 2012) have investigated the impact of loyalty on eWOM. For example, Son et al. (2012) investigated that open market loyalty has a positive effect on eWOM. As a result, the following hypothesis is proposed:

\section{H8: Loyalty is positively related to eWOM providing behaviour.}

Brand attitude. Brand attitude is defined as a favourable attitude toward the brand. Previous studies have found that consumers with strong loyalty to a brand usually create and spread positive information about the brand (Dick and Basu, 1994; Gounaris and Stathakopoulos 2004). Brand communities have members who are fans of a brand and also loyal toward the brand. Thus, most of the members actively engage in positive eWOM about the brand. It is argued by some researchers that the online setting - with readily available social networks and communication tools - helps participants to share positive eWOM about a brand (Yeh and Choi (2011). Additionally, it was found that eWOM generated by brand community members is not limited to the particular brand community. Loyal individuals pass the information they acquire from their peer community members to other people who do not belong to the community (Rialti et al., 2017; Yeh and Choi, 2011). A number of studies (e.g. Rialti et al., 2017; Yeh and Choi, 2011) investigated the connection between brand attitude and eWOM related behaviour. For example, Yeh and Choi (2011) studied the online community of MINI car fans, and found that online brand community members' brand attitude is positively related to their intention to provide eWOM. Thus, the following is hypothesised: 


\section{H9: Brand attitude is positively related to eWOM providing behaviour.}

\subsection{Personal conditions}

Personal conditions refer to the determinants of personal aspects that can have an impact on consumer behaviour (Luarn et al., 2015; Palka et al., 2009). Personal conditions in this study included altruism, affective commitment, normative commitment, opinion leadership, and self-enhancement.

Altruism. Altruism is an important concept in social psychology and refers to the aim of increasing welfare of one or more persons other than oneself (Cui et al., 2014). Based on human nature, individuals intrinsically have a need to support or help others without seeking any rewards in return (Wasko and Faraj, 2005). Researchers argue that consumers have a similar need to help others in the online environment, which makes it one of the reasons individuals take part in social groups (Baethge et al., 2016). After purchasing a product or service, consumers may be motivated to share information about their experience in order to help other people to make a purchase decision or to help the company attract new customers (Engel et al., 1993). Studies concerning the dissemination of eWOM in the network and social media environment have highlighted altruism as an important factor related to eWOM providing behaviour (Cui et al., 2014; Kim, 2017; Luarn et al., 2015; Reimer and Benkenstein, 2016; Yang, 2013). It was found by Cui et al. (2014) that altruistic motive has a positive correlation with individuals' motivation to spread eWOM in the online feedback system. Thus, it is hypothesised:

H10: Altruism is positively related to eWOM providing behaviour.

Commitment. According to the social exchange literature, commitment is defined as "the attachment an individual feels to a collective entity, such as a relation, a group, or organisation" (Lawler and Yoon, 1996, p.90). Commitment has a number of forms. First, affective (emotional) commitment, which is referred to as emotional attachment to, identification with, and involvement in an entity. Another form is normative commitment, which is motivated by an individual's moral obligation that they must fulfil. Some studies (Jin et al., 2009, 2010; Li et al., 2006) investigated commitment in the context of online communities. According to this line of research, commitment has a significant effect on a user's decision to participate in online communities. Affective commitment refers to an individual user's sense of emotional attachment and involvement with an online community. Normative commitment refers to users' responsibility to stay in the online community and help others. The study conducted by Jin et al. (2010) found that eWOM providing behaviour in online platforms is influenced by affective and normative commitment. Thus, the following hypotheses are proposed:

H11: Affective commitment is positively related to eWOM providing behaviour.

H12: Normative commitment is positively related to eWOM providing behaviour.

Opinion leadership. Opinion leaders influence public opinion by providing persuasive messages to their social network (Lazarsfeld et al., 1944). Opinion leadership can be defined 
as a domain-independent, trait-like set of personality characteristics that are stable over time and across respondent groups (Bobkowski, 2015). An opinion leader is someone who enjoys being the one to advertise certain products and brands to other people, shows behaviours such as online forwarding and chatting, and exchanges information with friends (Phelps et al., 2004). Opinion leaders influence the members of social communities and networks by disseminating information to other individuals (Chaney, 2001).

An increasing number of studies demonstrate that individuals' general behaviour and social media behaviour are related (Sheldon, 2013; Sun et al., 2006; Wright and Li, 2011). For example, extroverts and individuals who are less shy provide more communications on Facebook in comparison with introverts and people who are shyer (Sheldon, 2013). Thus, it can be seen that individuals replicate their off-line prosocial habits online (Wright and Li, 2011).

A number of studies (Bobkowski, 2015; Kucukemiroglu and Kara, 2015; Sun et al., 2006) investigated the relationship between opinion leadership and eWOM engagement behaviour. For example, using surveys of 250 American students in the context of music, Sun et al. (2006) found that opinion leadership positively influences eWOM providing behaviour. Thus, based on the above discussion it is hypothesised that:

\section{H13: Opinion leadership is positively related to eWOM providing behaviour.}

Self-enhancement. Individuals have a strong desire to maintain/increase the positivity of their self-concept (Leary, 2007). Self-enhancement (or self-improvement) refers to the situation when individuals try to present themselves positively by sharing information (Berger, 2014); this is classified as internally external motivation (Tong et al., 2007). It has been found that motivations for self-enhancement induce traditional WOM communications (Engel et al., 1993) and also eWOM communications (Wu et al., 2016). It is claimed that an individual's self-view influences their self-enhancement strategies (Gebauer et al., 2013). By using online feedback systems individuals have more chances to improve their image and obtain others' recognition by sharing information about product/services. It was found by previous research that the motivation of self-enhancement has a positive correlation with motivation to provide eWOM in online feedback systems (Cui et al., 2014). Thus, the following hypothesis is proposed:

\section{H14: Self-enhancement is positively related to eWOM providing behaviour.}

\subsection{Social conditions}

Social conditions emphasise the determinants of eWOM providing behaviour in consideration of recipients and their anticipated responses to recommendations. It has been argued that social conditions are important in influencing consumer decision making (Dholakia et al., 2004). Based on the studies by Luarn et al. (2015) and Palka et al. (2009), the social condition in this study is inclusive of six categories: influence of others, information influence, tie strength, homophily, community identity, and reciprocity. 
Interpersonal influence (influence of others and information influence). A number of studies found that eWOM is a powerful source of information due to interpersonal influence (Chu and Kim, 2011; Hansen and Lee, 2013; Shan and King, 2015). Interpersonal influence is defined as a social factor playing a crucial role in influencing consumers' decision making (D'Rozario and Choudhury, 2000). Researchers distinguish two dimensions of interpersonal influence: normative and informational influences (Bearden et al., 1989). Normative influence (influence of others) is the tendency to conform to the expectations of others, and affects attitudes, norms and values (Burnkrant and Cousineau, 1975). Norms play an important part in improving knowledge seeking and knowledge sharing (Bock et al., 2006; Choi and Scott, 2013). Information influence is defined as the tendency to accept information from other individuals who are perceived to be knowledgeable, and use this information as a guide in product, brand and store search (Bearden et al., 1989). The dual-process theory emphasises the effect of informative and normative influences on the credibility and usefulness of eWOM messages, which contributes to eWOM providing behaviour.

Norms present a form of social capital. Norms motivate members to participate in virtual communities, which indicates that there is a positive relationship between community participation and norms. Norms enable cooperation for the mutual benefit of community members (Choi and Scott, 2013). According to the Theory of Planned Behaviour (Ajzen and Fishbein, 1980), eWOM communications should not simply be a function of the consumers' attitude towards the behaviour but also be influenced by social norms. Consumers with high subjective norms should feel that other members of the community/SNS expect them to engage in eWOM providing behaviour to contribute to the community (Shan and King, 2015).

In the social networking context, informational influence drives useful eWOM behaviour. Chu and Kim (2011) found that there is a positive relationship between information influence and eWOM providing behaviour. The previous research (e.g. Christodoulides et al., 2012; Chu and Kim, 2011; Hansen and Lee, 2013) argues that in SNS normative and informational influence can influence individual's eWOM behaviour. Thus, it is hypothesised that:

\section{H15: Influence of others is positively related to eWOM providing behaviour.}

\section{H16: Information influence is positively related to eWOM providing behaviour.}

Tie strength. Tie strength refers to the depth of a relationship between source and information seeker (Mittal et al., 2008). Using a network analysis framework, Brown and Reingen (1987) demonstrated the impact of social ties in information sharing. Social ties can be classified as strong or weak (Granovetter, 1973). Individuals with strong ties have strong and close relationships, and provide practical and emotional support (e.g. family and friends); individuals with weak ties have more distant and less personal social relationships (e.g. acquaintances and colleagues) (Pigg and Crank, 2004). Both strong and weak ties can affect consumers' product/service choice, although some researchers claim that strong ties have a stronger impact on individual decision making (Brown and Reingen, 1987). The perceived tie strength developed through SNS motivates individuals to engage with each other and 
disseminate product/service-related information. Extension of social influence in technology acceptance research has found that both types of ties influence perceived usefulness of eWOM and engagement in a virtual community, although strong ties had a greater influence. Consumers can decide to persuade others based on strength of tie felt towards a network (Hansen and Lee, 2013). Granovetter (1973) argued that tie strength can play a critical role in a wide range of information exchange and idea-sharing. Thus, perceived tie strength encourages eWOM behaviour (Chu and Kim, 2011). Based on the above discussion it is hypothesised that:

\section{H17: Tie strength is positively related to eWOM providing behaviour.}

Homophily. Homophily refers to the degree to which two or more individuals who interact are similar in certain attributes (e.g. beliefs, education, social status, age, gender) (Rogers and Bhowmik, 1970). It is highlighted that homophily is a distinct concept from tie strength between individuals, as it is a different social motivator (Brown and Reingen, 1987; Hansen and Lee, 2013); similarity might lead to strong ties (deep relationships) (Brown and Reingen, 1987). It is argued that interpersonal communications are more likely to occur between individuals who are similar (Lazarsfeld and Merton, 1954). Thus, the information exchange occurs more frequently between individuals with some common qualities (Rogers, 1995; Rogers and Bhowmik, 1970). As a result, individuals with a higher level of perceived homophily are more likely to engage in eWOM with each other in order to make a purchase decision (Chu and Kim, 2011). It was argued by previous research (Saleem and Ellahi, 2017) that SNS users' perceived homophily with their contact is positively related to their engagement in eWOM behaviours in SNS. Several studies have investigated the relationship between homophily and eWOM providing behaviour. For example, Saleem and Ellahi (2017) conducted a survey among Facebook users in the context of fashion products and found that there is a positive relationship between homophily and eWOM providing behaviour. Based on the above discussion the following hypothesis can be proposed:

\section{H18: Homophily is positively related to eWOM providing behaviour.}

Reciprocity. Reciprocity refers to the benefit for individuals to engage in social exchange. When providers of information do not know each other, this type of reciprocity is called generalised exchange (Ekeh, 1974). In this type of exchange, the person who provides information is expecting returns in the future. Previous studies (e.g. Cheung and Lee, 2012; Wasko and Faraj, 2000) found that people who share knowledge in online communities value reciprocity. For example, a study by Cheung and Lee (2012) found that the perception of the opportunity for reciprocity is positively related to one's eWOM intention in the context of online reviews of restaurants. Thus, it can be proposed that:

\section{H19: Reciprocity is positively related to eWOM providing behaviour.}

Community identity. Identification refers to the process in which individuals see themselves as one with another person or group of people (Nahapiet and Ghoshal, 1998). Identification is also defined as an individual's sense of belonging and a positive feeling toward a virtual community (Chiu et al., 2006). Previous research has suggested that identification has a 
positive effect on the intention to provide information in online brand communities (Yeh and Choi, 2011). It also provides a strong motive towards eWOM behaviour (Hennig-Thurau and Walsh, 2003). Some studies (e.g. Chi-Hsing, 2014; Horng, 2016; Yoo et al., 2013) investigated the link between community identity and eWOM related behaviour. For example, Horng (2016) found that identification is positively associated with a higher level of participation intention by both passive and active users in online communities. Thus, the following is hypothesised:

H20: Community identity is positively related to eWOM providing behaviour.

\section{Method}

\subsection{Literature search method}

In order to perform a meta-analysis, peer-reviewed journal articles on eWOM communications in the marketing context were collected. To avoid publication bias, this research employed a multi-channel literature search (Scopus, Web of Science, and EBSCO). Keywords such as "Electronic word-of-mouth" OR "Electronic word of mouth" OR "eWOM" OR "Internet word-of-mouth" OR "Internet word of mouth" OR "iWOM" OR "Online word-of-mouth" OR "Online word of mouth" OR "Virtual word-of-mouth" OR "vWOM" OR "Virtual word of mouth" were used. Through this process more than 590 articles published between 2000 and 2017 were identified.

Taking into consideration the research aim, several selection criteria were applied to the initial 590 articles garnered from the search. To be included in the final sample the article needed to be a published or working academic paper and should be focused on eWOM providing behaviour. As a result of these criteria, 78 articles remained in the collection. However, the articles also needed to contain the relevant statistical details for meta-analysis (sample size, Pearson correlation, and significance of the relationships), which resulted in the removal of 27 studies. Therefore, a total of 51 articles remained based on the criteria specified (see Appendix 1).

It is argued by Kirca et al. (2005) that meta-analysis can be conducted with at least three studies. In total 128 factors influencing intention to provide eWOM communications were identified. However, from a detailed review of these articles it was found that only 20 factors were examined three or more times and had reported correlations with intention to engage in eWOM communications, and thus could be included in the analysis. Some studies used different labels for the same construct, discovered through close examination of the measurement scales. For instance, information usefulness was also named as information helpfulness or diagnosticity. 


\subsection{Meta-analysis}

As the number of studies in eWOM research is growing dramatically, it is important to analyse and discuss their collective insight, to enable more generalisable conclusions in comparison with the ones presented in any single primary study (Geyskens et al., 2009; Schmidt and Hunter, 2014). Meta-analysis is an alternative to a qualitative and descriptive literature analysis (Glass 1976), providing an opportunity to critically evaluate and statistically combine results of previous studies (Chang and Huang, 2020; Jeyaraj et al., 2020; Fagard et al., 1996).

Meta-analysis originated from Fisher's "combining $p$ values" method (Glass, 1976). Metaanalysis has become a popular and valuable tool for researchers, which helps to quantitatively integrate research findings from a large number of studies (Floyd et al., 2014). This technique allows a mathematical combination of correlations between two or more variables in order to reconcile inconsistent findings (Hong et al., 2017). To run meta-analysis, a trial version of Comprehensive Meta-analysis Software (see https://www.meta-analysis.com/) was used. This software is a popular tool among researchers to perform meta-analysis (e.g. Hong et al., 2017).

In order to conduct the meta-analysis, effect sizes were extracted from the included studies. The effected size can be defined as "the degree to which the phenomenon is present in the population or the degree to which the null hypothesis is false" (p.9, Cohen, 1988). In the current paper we used the correlation coefficient $r$ as the effect size. The meta-analysis includes the following steps. First step includes calculation of the Fisher's $\mathrm{Z}$ and combination of effect sizes. Second step includes testing the significance of the combined effect sizes. The p-value associated with the combined effect size shows its statistical significance (Hong et al., 2017). Based on the result of Q-statistics, which rejects the homogeneity assumption across studies (Martin, 2008), this study adopted random-effect model for meta-analysis.

By using correlation coefficients between each pair of variables and sample size, Comprehensive Meta-Analysis Software generates a cumulative correlation coefficient (Avg $(r)$ ), effect sizes ( $p(E S))$, Z-value, and 95\% lower and upper confidence interval levels. In line with previous research on meta-analysis (e.g. Dwivedi et al., 2019; Jeyaraj et al., 2006), variables for the current study were only selected if the relationships between the independent and dependent construct had been investigated by at least three or more previous studies using different datasets (Kirca et al., 2005). The reason for this restriction was to obtain appropriate correlation coefficients.

\section{Results}

The results of meta-analysis (Table 3) indicates that 16 out of the 20 hypothesised relationships were found to be significant overall. Particularly strong correlations were found between intention to engage in eWOM and economic incentives $(\mathrm{r}=0.420)$, self-enhancement $(\mathrm{r}=0.458)$, information usefulness $(\mathrm{r}=0.446)$, affective commitment $(\mathrm{r}=0.563)$, normative commitment $(\mathrm{r}=0.468)$, customer satisfaction $(\mathrm{r}=0.445)$, altruism $(0.397)$, opinion seeking $(\mathrm{r}=0.594)$, opinion leadership $(\mathrm{r}=0.425)$, brand attitude $(\mathrm{r}=0.708)$, and community identity 
$(\mathrm{r}=0.563)$. Correlations between intention to engage in eWOM and tie strength $(\mathrm{r}=0.223)$, information influence $(\mathrm{r}=0.311)$, homophily $(\mathrm{r}=0.172)$, loyalty $(\mathrm{r}=0.348)$, and trust in web eWOM services $(r=0.376)$ were weaker. 